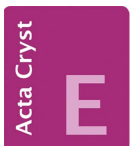

CRYSTALLOGRAPHIC COMMUNICATIONS

ISSN 2056-9890

Received 28 May 2020

Accepted 3 June 2020

Edited by W. T. A. Harrison, University of Aberdeen, Scotland

‡ Additional correspondence author, e-mail: edwardt@sunway.edu.my.

Keywords: crystal structure; 1,2,3-triazole; Hirshfeld surface analysis; computational chemistry.

CCDC reference: 2007664

Supporting information: this article has supporting information at journals.iucr.org/e

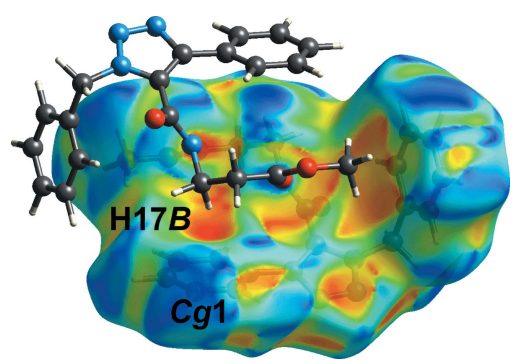

OPEN Ә ACCESS

\section{Methyl 3-[(1-benzyl-4-phenyl-1H-1,2,3-triazol-5- yl)formamido]propanoate: crystal structure, Hirshfeld surface analysis and computational chemistry}

\author{
Ignez Caracelli, ${ }^{a *}$ Julio Zukerman-Schpector, ${ }^{\mathrm{b}}$ Huey Chong Kwong ${ }^{\mathrm{c}}$ and
} Edward R. T. Tiekink ${ }^{\mathrm{c}} \ddagger$

àDepartmento de Física, Universidade Federal de São Carlos, 13565-905 São Carlos, SP, Brazil, baboratório de Cristalografia, Esterodinâmica e Modelagem Molecular, Departamento de Química, Universidade Federal de São Carlos, 13565-905 São Carlos, SP, Brazil, and ${ }^{\mathbf{c}}$ Research Centre for Crystalline Materials, School of Science and Technology,

Sunway University, 47500 Bandar Sunway, Selangor Darul Ehsan, Malaysia. *Correspondence e-mail: ignez@df.ufscar.br

The title compound, $\mathrm{C}_{20} \mathrm{H}_{20} \mathrm{~N}_{4} \mathrm{O}_{3}$, is constructed about a tri-substituted 1,2,3triazole ring, with the substituent at one $\mathrm{C}$ atom flanked by the $\mathrm{C}$ and $\mathrm{N}$ atoms being a substituted amide group, and with the adjacent $\mathrm{C}$ and $\mathrm{N}$ atoms bearing phenyl and benzyl groups, respectively; the dihedral angle between the pendant phenyl rings is $81.17(12)^{\circ}$, indicative of an almost orthogonal disposition. In the crystal, pairwise amide- $\mathrm{N}-\mathrm{H} \cdots \mathrm{O}$ (carbonyl) hydrogen bonds lead to a centrosymmetric dimer incorporating methylene- $\mathrm{C}-\mathrm{H} \cdots \pi$ (benzene) interactions. The dimers are linked into a supramolecular layer in the $a b$ plane via methylene-C $-\mathrm{H} \cdots \mathrm{N}(\mathrm{azo})$ and benzene-C$-\mathrm{H} \cdots \mathrm{O}$ (amide) interactions; the layers stack along the $c$-axis direction without directional interactions between them. The above-mentioned intermolecular contacts are apparent in the analysis of the calculated Hirshfeld surface, which also provides evidence for short interlayer H...C contacts with a significant dispersion energy contribution.

\section{Chemical context}

The title 1,2,3-triazole-5-carboxamide derivative, (I), was recently prepared and characterized from a palladium-catalysed aminocarbonylation reaction with the use of dimethyl carbonate as a sustainable solvent (de Albuquerque et al., 2019). The motivation for preparing such molecules rests with the known pharmacological activity of these and related 1,2,3triazole derivatives (Bonandi et al., 2017). Unambiguous structure determination of (I) is reported herein, via X-ray crystallography, as is a detailed analysis of the supramolecular association by Hirshfeld surface analysis and computational chemistry.<smiles>COC(=O)CCNC(=O)c1c(-c2ccccc2)nnn1Cc1ccccc1</smiles>

\section{Structural commentary}

The molecular structure of (I), Fig. 1, features a tri-substituted 1,2,3-triazole ring. The five-membered ring is strictly planar 
Table 1

Hydrogen-bond geometry $\left(\AA{ }^{\circ}\right)$.

$C g 1$ is the centroid of the (C10-C15) ring.

\begin{tabular}{lllll}
\hline$D-\mathrm{H} \cdots A$ & $D-\mathrm{H}$ & $\mathrm{H} \cdots A$ & $D \cdots A$ & $D-\mathrm{H} \cdots A$ \\
\hline $\mathrm{N} 4-\mathrm{H} 4 N \cdots \mathrm{O} 2^{\mathrm{i}}$ & $0.86(3)$ & $2.04(3)$ & $2.884(4)$ & $167(3)$ \\
$\mathrm{C} 3-\mathrm{H} 3 B \cdots \mathrm{N} 2^{\mathrm{ii}}$ & 0.97 & 2.55 & $3.495(5)$ & 165 \\
$\mathrm{C} 15-\mathrm{H} 15 \cdots \mathrm{O} 1^{\mathrm{iii}}$ & 0.93 & 2.51 & $3.335(5)$ & 148 \\
$\mathrm{C} 17-\mathrm{H} 17 B \cdots C g 1^{\mathrm{i}}$ & 0.97 & 2.71 & $3.640(4)$ & 161 \\
\hline
\end{tabular}

Symmetry codes: (i) $\quad-x+1,-y,-z+1 ; \quad$ (ii) $\quad-x,-y+1,-z+1$; $\quad$ (iii) $-x+1,-y+1,-z+1$

with the r.m.s. deviation of the fitted atoms being $0.0021 \AA$. Within the ring, the lengthening of the formal azo-N2-N3

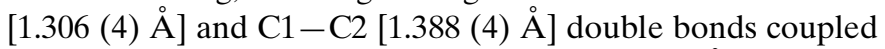
with the shortening of the $\mathrm{N} 1-\mathrm{N} 2[1.341$ (4) $\AA$ ], $\mathrm{C} 1-\mathrm{N} 3$ [1.368 (4) $\AA$ ] and $\mathrm{C} 2-\mathrm{N} 1$ [1.347 (4) $\AA$ ] bonds from their standard double/single bond values, are indicative of significant delocalization of $\pi$-electron density over the ring atoms. While the N1-bound C3-atom lies 0.131 (6) $\AA$ out of the plane of the ring, the C1- and C2-bound C10 [0.012 (6) $\AA$ ] and C16 [0.008 (6) ^] atoms are effectively co-planar with the ring. The terminal residues are twisted out of the plane of the central ring as seen in the $(\mathrm{C} 1, \mathrm{C} 2, \mathrm{~N} 1-\mathrm{N} 3) /(\mathrm{C} 4-\mathrm{C} 9)\left[74.46(13)^{\circ}\right]$, $(\mathrm{C} 1, \mathrm{C} 2, \mathrm{~N} 1-\mathrm{N} 3) /(\mathrm{C} 10-\mathrm{C} 15)\left[28.10(17)^{\circ}\right]$ and $(\mathrm{C} 1, \mathrm{C} 2, \mathrm{~N} 1-\mathrm{N} 3) /$ $(\mathrm{C} 16, \mathrm{~N} 4, \mathrm{O} 1)\left[47.1(2)^{\circ}\right]$ dihedral angles. The dihedral angle between the terminal phenyl rings is $81.17(12)^{\circ}$ indicating a close to orthogonal disposition. There is a twist in the amide residue as seen in the value of the $\mathrm{N} 4-\mathrm{C} 17-\mathrm{C} 18-\mathrm{C} 19$ torsion angle of $73.6(4)^{\circ}$, indicating a $(+)$ syn-clinal relationship. This results in a dihedral angle close to orthogonal for the amide $(\mathrm{C} 16, \mathrm{~N} 4, \mathrm{O} 1)$ and carboxylate $(\mathrm{C} 19, \mathrm{O} 2, \mathrm{O} 3)$ residues, i.e. $73.6(4)^{\circ}$.

\section{Supramolecular features}

The molecular packing in (I) features several identifiable points of contact, Table 1 . The most evident of these are

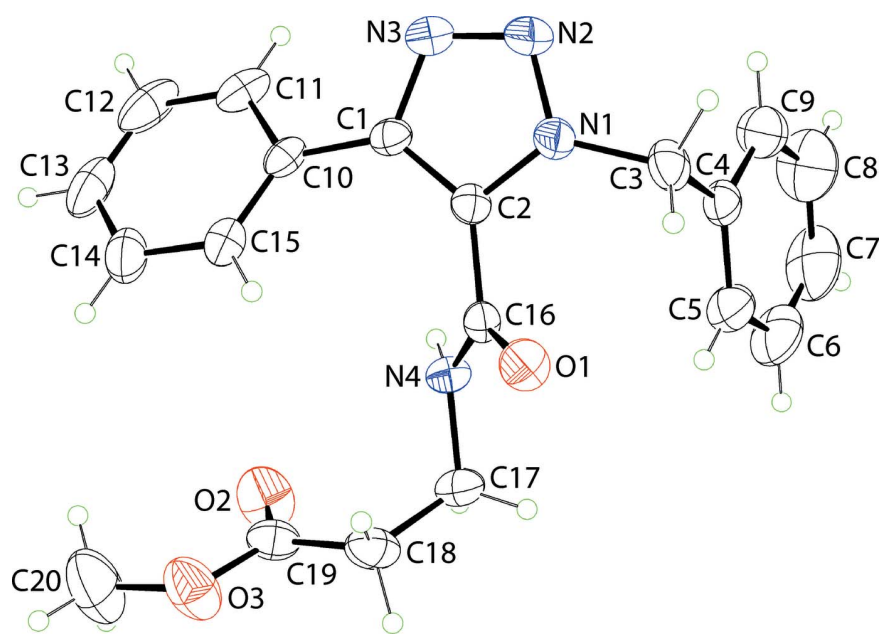

Figure 1

The molecular structure of (I), showing the atom-labelling scheme and displacement ellipsoids at the $35 \%$ probability level.
amide-N4-H...O2(carbonyl) hydrogen bonds occurring between centrosymmetrically related molecules to give the dimer shown in Fig. 2(a). The molecules in the dimer are linked via a 12 -membered $\left\{\cdots \mathrm{OC}_{3} \mathrm{NH}\right\}_{2}$ synthon and additional stability to the assembly is provided by methylene$\mathrm{C} 17-\mathrm{H} \cdots \pi$ (benzene) interactions. The dimeric aggregates are connected into a supramolecular layer propagating in the $a b$ plane via methylene-C3- $\mathrm{H} \cdots \mathrm{N} 2$ (azo) and benzene-C15$\mathrm{H}$...O1(amide) interactions, Fig. 2(b). The layers stack in an $\ldots A B A B \ldots$ pattern along the $c$ axis and inter-digitate to potentially form $\pi-\pi$ interactions. However, these are not apparent, Fig. 2(c). A more detailed analysis of the interactions occurring in the inter-layer region is provided by an analysis of the calculated Hirshfeld surfaces.

(a)
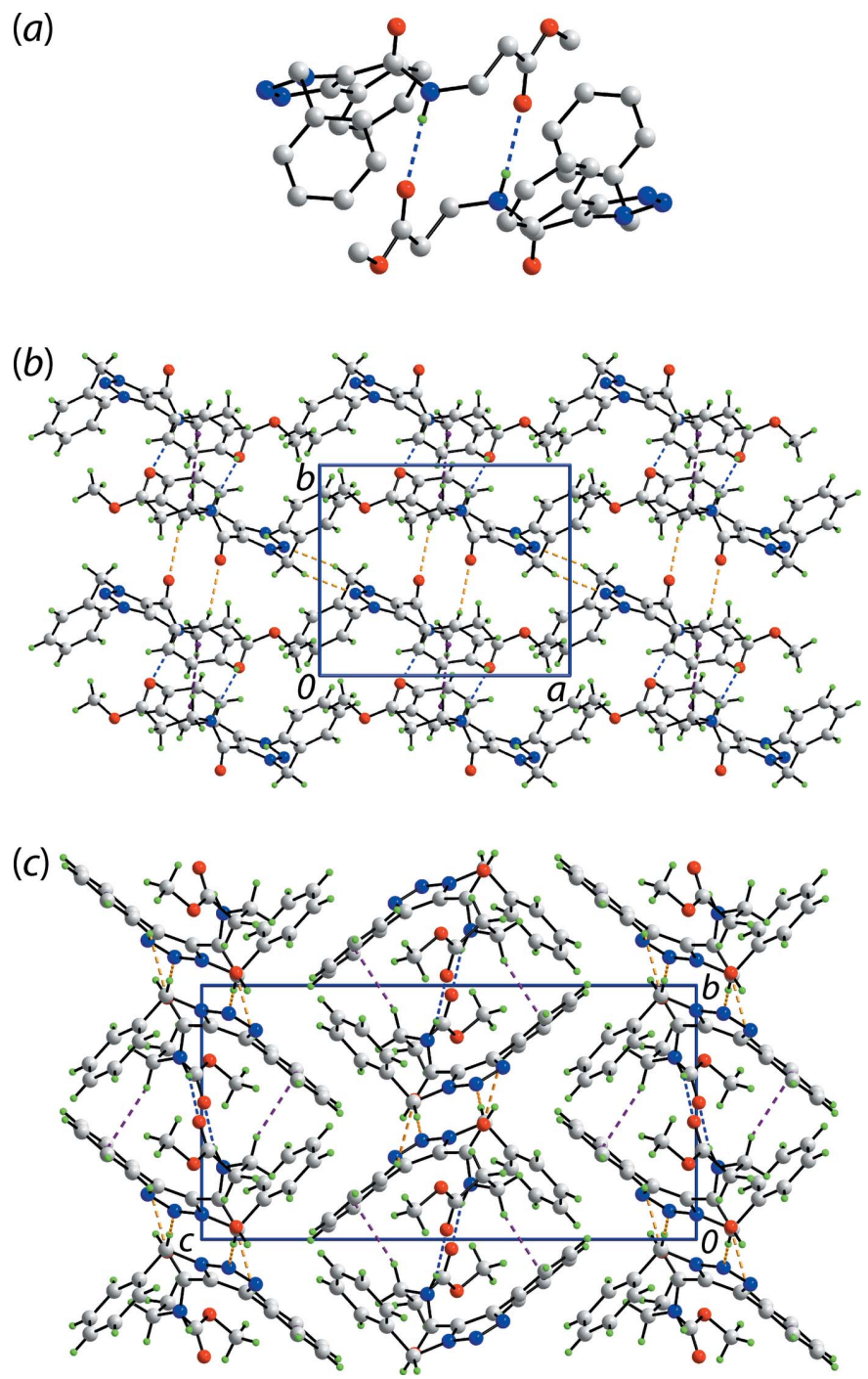

Figure 2

Molecular packing in (I): (a) supramolecular dimer sustained by amide$\mathrm{N} 4-\mathrm{H} \cdots \mathrm{O} 2$ (carbonyl) hydrogen bonds ( $\mathrm{H}$ atoms omitted for clarity), (b) layer where the dimers of $(a)$ are connected by methylene-C3$\mathrm{H} \cdot \mathrm{N}(\mathrm{azo})$ and benzene-C15- $\mathrm{H} \cdots \mathrm{O} 1$ (amide) interactions [the methylene-C17 $-\mathrm{H} \cdots \pi$ (benzene) interactions occur within the dimers] and $(c)$ a view of the unit-cell contents shown in projection down the $a$ axis. The $\mathrm{N}-\mathrm{H} \cdots \mathrm{O}, \mathrm{C}-\mathrm{H} \cdots \mathrm{O}$ and $\mathrm{C}-\mathrm{H} \cdots \pi$ interactions are shown as blue, orange and purple dashed lines, respectively. 
Table 2

Summary of short interatomic contacts $(\AA)$ in $(\mathrm{I})^{a}$.

\begin{tabular}{lll}
\hline Contact & Distance & Symmetry operation \\
\hline $\mathrm{H} 4 N \cdots \mathrm{O} 2^{b}$ & 1.90 & $-x+1,-y,-z+1$ \\
$\mathrm{H} 3 B \cdots \mathrm{N} 2^{b}$ & 2.44 & $-x+1,-y+1,-z+1$ \\
$\mathrm{H} 15 \cdots \mathrm{O} 1^{b}$ & 2.38 & $-x,-y+1,-z+1$ \\
$\mathrm{H} 7 \cdots \mathrm{C} 5$ & 2.63 & $-x, y-\frac{1}{2},-z+\frac{1}{2}$ \\
$\mathrm{H} 17 A \cdots \mathrm{C} 12$ & 2.72 & $x,-y+\frac{1}{2}, z-\frac{1}{2}$ \\
$\mathrm{H} 12 \cdots \mathrm{C} 15$ & 2.73 & $-x+1, y-\frac{1}{2},-z+\frac{3}{2}$ \\
\hline
\end{tabular}

Notes: (a) The interatomic distances are calculated in Crystal Explorer 17 (Turner et al., 2017) whereby the $X-\mathrm{H}$ bond lengths are adjusted to their neutron values. (b) These interactions correspond to those reported in Table 1.

\section{Hirshfeld surface analysis}

In order to probe the interaction between molecules of (I) in the crystal, Hirshfeld surfaces mapped with the normalized contact distance $d_{\text {norm }}$ (McKinnon et al., 2004), electrostatic potential (Spackman et al., 2008) and two-dimensional fingerprint plots were calculated using Crystal Explorer 17 (Turner et al., 2017) by established procedures (Tan et al., 2019). The electrostatic potentials were calculated using the wavefunction at the HF/STO-3 G level of theory. The bright-
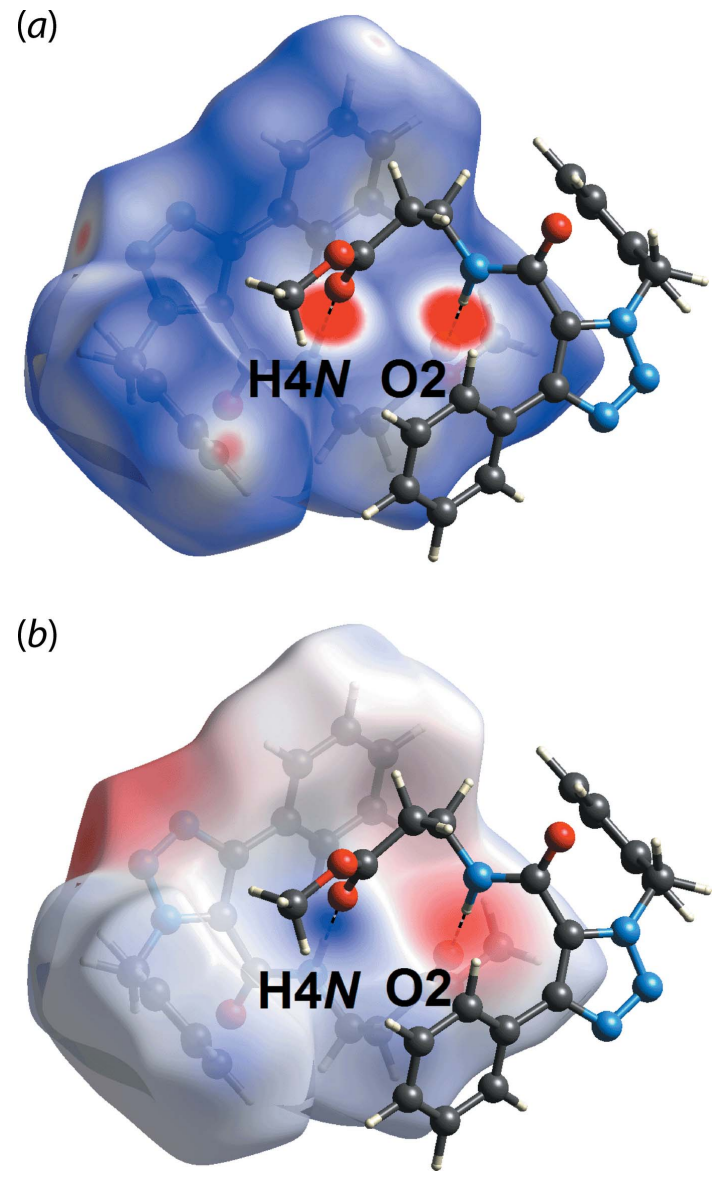

Figure 3

Views of the Hirshfeld surface for (I) mapped over $(a) d_{\text {norm }}$ in the range -0.249 to +1.397 arbitrary units and $(b)$ the electrostatic potential map in the range -0.097 to 0.134 atomic units, highlighting $\mathrm{N}-\mathrm{H} \cdots \mathrm{O}$ hydrogen bonding. (a)

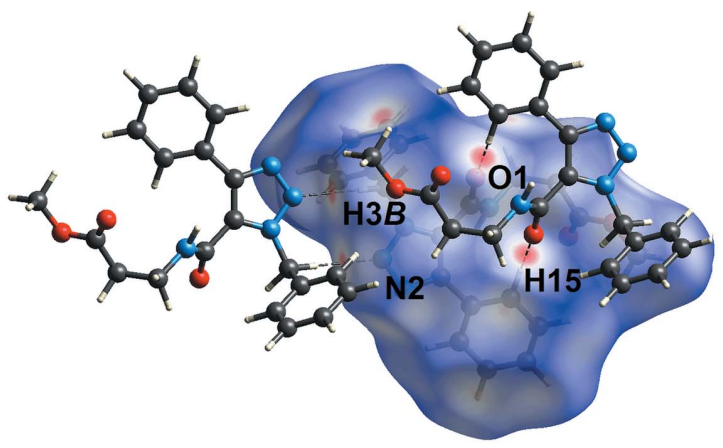

(b)

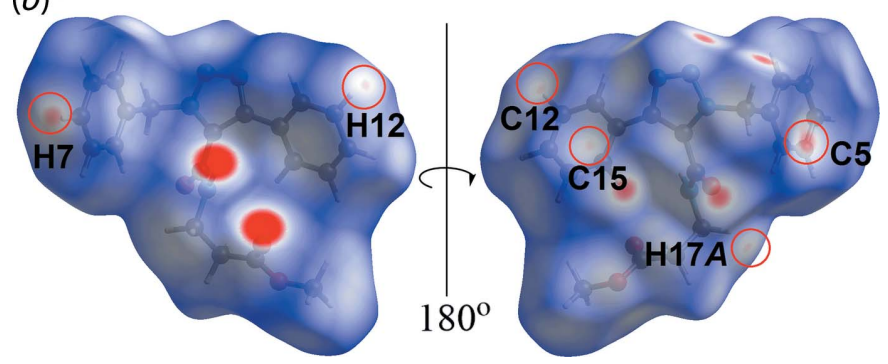

Figure 4

Views of the Hirshfeld surface mapped over $d_{\text {norm }}$ for (I) in the range -0.249 to +1.397 arbitrary units, highlighting $(a)$ weak $\mathrm{C}-\mathrm{H} \cdots \mathrm{N}$ and $\mathrm{C}-$ $\mathrm{H} \cdots \mathrm{O}$ interactions and $(b)$ short $\mathrm{H} \cdots \mathrm{C}$ contacts, highlighted within red circles.

red spots on the Hirshfeld surface mapped over $d_{\text {norm }}$ in Fig. 3(a), i.e. near the amide- $\mathrm{H} 4 \mathrm{~N}$ and carbonyl-O2 atoms, correspond to the amide- $\mathrm{N}-\mathrm{H} 4 \mathrm{~N} \cdots \mathrm{O} 2$ (carbonyl) hydrogen bond (Table 1). This hydrogen bond is also reflected in Hirshfeld surface mapped over the electrostatic potential Fig. 3(b), where the blue (positive electrostatic potential) and red (negative electrostatic potential) regions are apparent around the amide- $\mathrm{H} 4 \mathrm{~N}$ and carbonyl-O2 atoms, respectively.

The methylene-C3-H.N2(azo) and benzene-C15$\mathrm{H} 15$. . O1(amide) interactions are observed as faint-red spots on the $d_{\text {norm }}$-mapped Hirshfeld surface in Fig. 4(a), with a distance of $\sim 0.3 \AA$ shorter than the sum of their van der Waals radii, Table 2 . The other faint red spots near the benzyl (C5, $\mathrm{C} 12, \mathrm{C} 15, \mathrm{H} 7$ and $\mathrm{H} 12)$ and methylene $(\mathrm{H} 17 A)$ atoms in

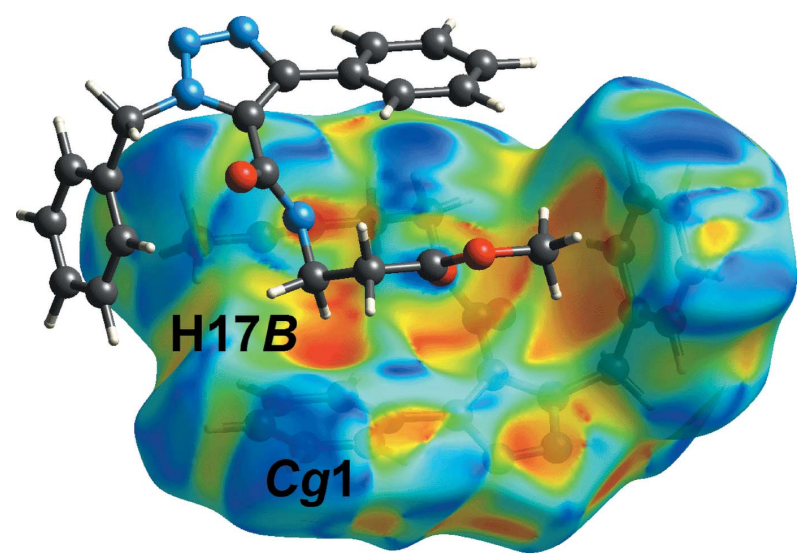

Figure 5

A view of the Hirshfeld surface for (I) mapped with the shape-index property, highlighting the intermolecular $\mathrm{C}-\mathrm{H} \cdots \pi$ interaction. 
Table 3

Percentage contributions of interatomic contacts to the Hirshfeld surface for (I).

\begin{tabular}{lr}
\hline Contact & Percentage contribution \\
\hline $\mathrm{H} \cdots \mathrm{H}$ & 46.7 \\
$\mathrm{H} \cdots \mathrm{C} / \mathrm{C} \cdots \mathrm{H}$ & 24.9 \\
$\mathrm{H} \cdots \mathrm{O} / \mathrm{O} \cdots \mathrm{H}$ & 14.4 \\
$\mathrm{H} \cdots \mathrm{N} / \mathrm{N} \cdots \mathrm{H}$ & 12.6 \\
$\mathrm{O} \cdots \mathrm{C} / \mathrm{C} \cdots \mathrm{O}$ & 1.0 \\
$\mathrm{O} \cdots \mathrm{O}$ & 0.4 \\
\hline
\end{tabular}

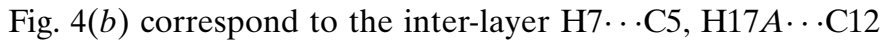
and $\mathrm{H} 12 \cdots \mathrm{C} 15$ short contacts listed in Table 2. Even though the $\mathrm{C}-\mathrm{H} \cdots \pi$ interaction, Table 1 , was not manifested on the $d_{\text {norm-mapped Hirshfeld surface, this interaction shows up as a }}$ distinctive orange 'pothole' on the shape-index-mapped Hirshfeld surface, Fig. 5.

The overall two-dimensional fingerprint plot for the Hirshfeld surface of (I) is shown with characteristic pseudosymmetric wings in the upper left and lower right sides of the $d_{\mathrm{e}}$ and $d_{\mathrm{i}}$ diagonal axes, respectively, in Fig. $6(a)$. The delin-

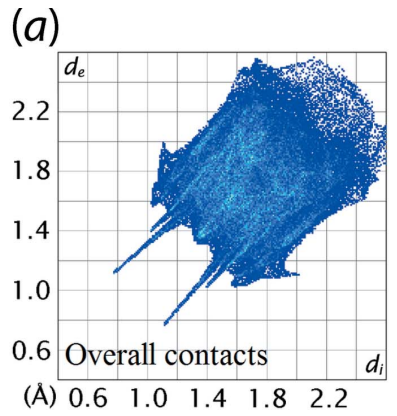

(b)

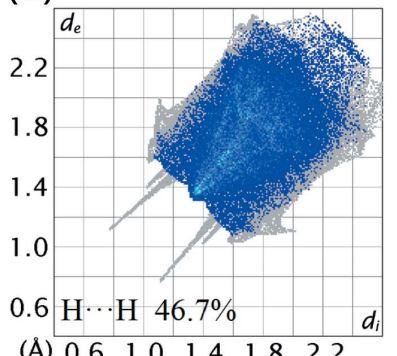

(d)

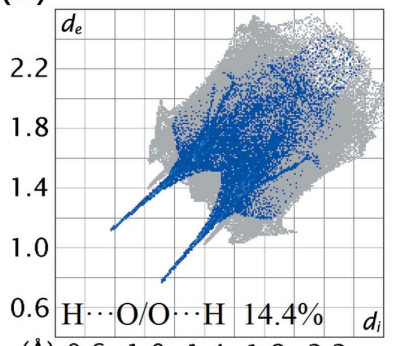

(A) $\begin{array}{llllll}0.6 & 1.0 & 1.4 & 1.8 & 2.2\end{array}$ (c)

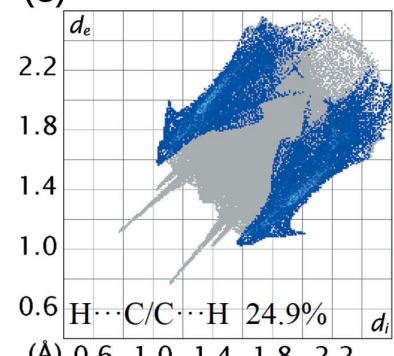

(A) $\begin{array}{llllll}0.6 & 1.0 & 1.4 & 1.8 & 2.2\end{array}$

(e)

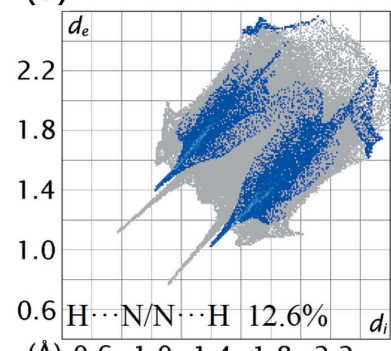

Figure 6

(a) The full two-dimensional fingerprint plot for (II) and (b)-(e) those delineated into $\mathrm{H} \cdots \mathrm{H}, \mathrm{H} \cdots \mathrm{C} / \mathrm{C} \cdots \mathrm{H}, \mathrm{H} \cdots \mathrm{O} / \mathrm{O} \cdots \mathrm{H}$ and $\mathrm{H} \cdots \mathrm{N} / \mathrm{N} \cdots \mathrm{H}$ contacts, respectively.
Table 4

Summary of interaction energies $\left(\mathrm{kJ} \mathrm{mol}^{-1}\right)$ calculated for (I).

\begin{tabular}{lrrrrrr}
\hline Contact & $R(\AA)$ & $E_{\text {ele }}$ & $E_{\text {pol }}$ & $E_{\text {dis }}$ & $E_{\text {rep }}$ & $E_{\text {tot }}$ \\
\hline Intra-later & & & & & & \\
$\mathrm{N} 4-\mathrm{H} 4 N \cdots \mathrm{O} 2^{\mathrm{i}}$ & 5.21 & -73.7 & -14.9 & -84.6 & 94.6 & -104.2 \\
$\mathrm{C} 15-\mathrm{H} 15 \cdots \mathrm{O} 1^{\mathrm{iii}}$ & 5.57 & -21.8 & -5.7 & -56.7 & 34.0 & -55.0 \\
$\mathrm{C} 3-\mathrm{H} 3 B \cdots \mathrm{N}^{2 i}$ & 9.97 & -21.4 & -6.2 & -20.5 & 25.1 & -29.6 \\
$\mathrm{H} 20 B \cdots \mathrm{N} 3^{\text {iv }}+$ & & & & & & \\
$\mathrm{H} 9 \cdots \mathrm{O}^{\mathrm{v}}+$ & & & & & & \\
$\mathrm{H} 8 \cdots \mathrm{H} 18 A^{\mathrm{v}}$ & 11.43 & -5.1 & -1.6 & -14.8 & 6.9 & -15.2 \\
$\mathrm{H} 8 \cdots \mathrm{H} 14^{\mathrm{vi}}$ & 12.81 & -1.4 & -0.5 & -9.8 & 2.2 & -9.0 \\
$\mathrm{H} 8 \cdots \mathrm{H} 11^{\mathrm{vii}}$ & 9.77 & -1.2 & -0.4 & -8.6 & 1.6 & -8.0 \\
$\mathrm{H} 20 C \cdots \mathrm{H} 20 C^{\text {viii }}$ & 14.84 & 1.3 & -0.2 & -3.1 & 0.6 & -1.1 \\
Inter-layer & & & & & & \\
H17 $A \cdots \mathrm{C} 12^{\text {ix }}$ & 9.37 & -11.3 & -3.4 & -22.7 & 14.8 & -25.1 \\
$\mathrm{H} 12 \cdots \mathrm{C} 15^{x}$ & 10.15 & -5.1 & -1.2 & -16.3 & 10.0 & -14.3 \\
$\mathrm{H} 7 \cdots \mathrm{C} 5^{\text {xi }}$ & 12.03 & -3.2 & -0.4 & -14.0 & 11.5 & -8.7 \\
\hline
\end{tabular}

Notes: Symmetry operations: (i) $-x+1,-y,-z+1$; (ii) $-x+1,-y+1,-z+1$; (iii) $-x$, $-y+1,-z+1$; (iv) $x+1, y, z$; (v) $x-1, y, z$; (vi) $x-1,-y+\frac{1}{2}, z-\frac{1}{2}$; (vii) $-x,-y,-z+1$; (viii) $-x+2,-y,-z+1$; (ix) $x,-y+\frac{1}{2},-z-\frac{1}{2} ;(x)-x+1, y-\frac{1}{2},-z+\frac{3}{2}$; (xi) $-x, y-\frac{1}{2}$, $-z+\frac{1}{2}$

eated $\mathrm{H} \cdots \mathrm{H}, \mathrm{H} \cdots \mathrm{C} / \mathrm{C} \cdots \mathrm{H}, \mathrm{H} \cdots \mathrm{O} / \mathrm{O} \cdots \mathrm{H}$ and $\mathrm{H} \cdots \mathrm{N} / \mathrm{N} \cdots \mathrm{H}$ contacts from the overall two-dimensional fingerprint plot are illustrated in Fig. 6(b)-(e), respectively. The percentage contributions from different interatomic contacts to the Hirshfeld surface of (I) are summarized in Table 3. The greatest contribution to the overall Hirshfeld surface are due to $\mathrm{H} \cdot \mathrm{H}$ contacts, which contribute $46.7 \%$. However, the $\mathrm{H} \cdot \mathrm{H}$ contacts appear as a square-like distribution with a small beak at $d_{\mathrm{e}}=d_{\mathrm{i}} \sim 2.6 \AA$ in Fig. $6(b)$, corresponding to $\mathrm{H} 8 \cdot \mathrm{H} 11 \simeq 2.67 \AA$ (symmetry operation: $-x,-y,-z+1$ ) indicating that all $\mathrm{H} \cdots \mathrm{H}$ contacts have long-range characteristics. The $\mathrm{H} \cdots \mathrm{C} / \mathrm{C} \cdots \mathrm{H}$ contacts on the Hirshfeld surface, which contribute $24.9 \%$ to the overall surface, Fig. $6(c)$, reflect the $\mathrm{C}-\mathrm{H} \cdots \pi$ interaction and $\mathrm{C} \cdots \mathrm{H}$ short contacts as discussed above. Consistent with the $\mathrm{C}-\mathrm{H} \cdots \mathrm{O}$ and $\mathrm{C}-$ $\mathrm{H} \cdots \mathrm{N}$ interactions occurring in the crystal, $\mathrm{H} \cdots \mathrm{O} / \mathrm{O} \cdots \mathrm{H}$ and $\mathrm{H} \cdots \mathrm{N} / \mathrm{N} \cdots \mathrm{H}$ contacts contribute 14.4 and $12.6 \%$, respectively, to the overall Hirshfeld surface. These appear as two sharp symmetric spikes in the fingerprint plots at $d_{\mathrm{e}}+d_{\mathrm{i}} \simeq 1.9$ and $2.4 \AA$ in Fig. $6(d)$ and $(e)$, respectively. The contribution from the other interatomic contacts summarized in Table 2 has a negligible influence on the calculated Hirshfeld surface of (I).

\section{Energy frameworks}

The pairwise interaction energies between the molecules in the crystal of (I) were calculated using the 6-31G(d,p) basis set at the B3LYP level of theory. The total energy comprises four terms, i.e. the electrostatic $\left(E_{\mathrm{ele}}\right)$, polarization $\left(E_{\mathrm{pol}}\right)$, dispersion $\left(E_{\mathrm{dis}}\right)$ and exchange-repulsion $\left(E_{\mathrm{rep}}\right)$ energy terms and were calculated with Crystal Explorer 17 (Turner et al., 2017). The benchmarked energies were scaled according to Mackenzie et al. (2017) while $E_{\text {ele }}, E_{\mathrm{pol}}, E_{\mathrm{dis}}$, and $E_{\mathrm{rep}}$ were scaled as 1.057, 0.740, 0.871 and 0.618, respectively (Edwards et al., 2017). The energies for the identified intermolecular interactions are tabulated in Table 4. As anticipated, the greatest stabilization energy, with approximately equal contributions 
from $E_{\text {ele }}$ and $E_{\text {dis }}$, arises from the conventional amide-N$\mathrm{H} 4 N$. O 2 (carbonyl) hydrogen bond. The next most significant energies of stabilization arise from the methylene-C3$\mathrm{H} \cdot \mathrm{N} 2$ (azo) (dominated by $E_{\mathrm{dis}}$ ) and benzene-C15H15...O1(amide) (approximately equal contributions from $E_{\text {ele }}$ and $\left.E_{\text {dis }}\right)$ interactions. In terms of energy, the next most significant contributions comes from an interaction in the inter-layer region, namely the $\mathrm{H} 17 A \cdots \mathrm{C} 12$ contact, Table 4. As for the other identified inter-layer contacts, $E_{\text {dis }}$ is the dominant contributor. Views of the energy framework diagrams down $a$ axis are shown in Fig. 7 and confirm the crystal to be mainly stabilized by electrostatic and dispersive forces with a clear dominance from the latter. The total $E_{\text {ele }}$ of all pairwise interactions sum to $-142.9 \mathrm{~kJ} \mathrm{~mol}^{-1}$, while the total $E_{\text {dis }}$ computes to $-251.1 \mathrm{~kJ} \mathrm{~mol}^{-1}$.
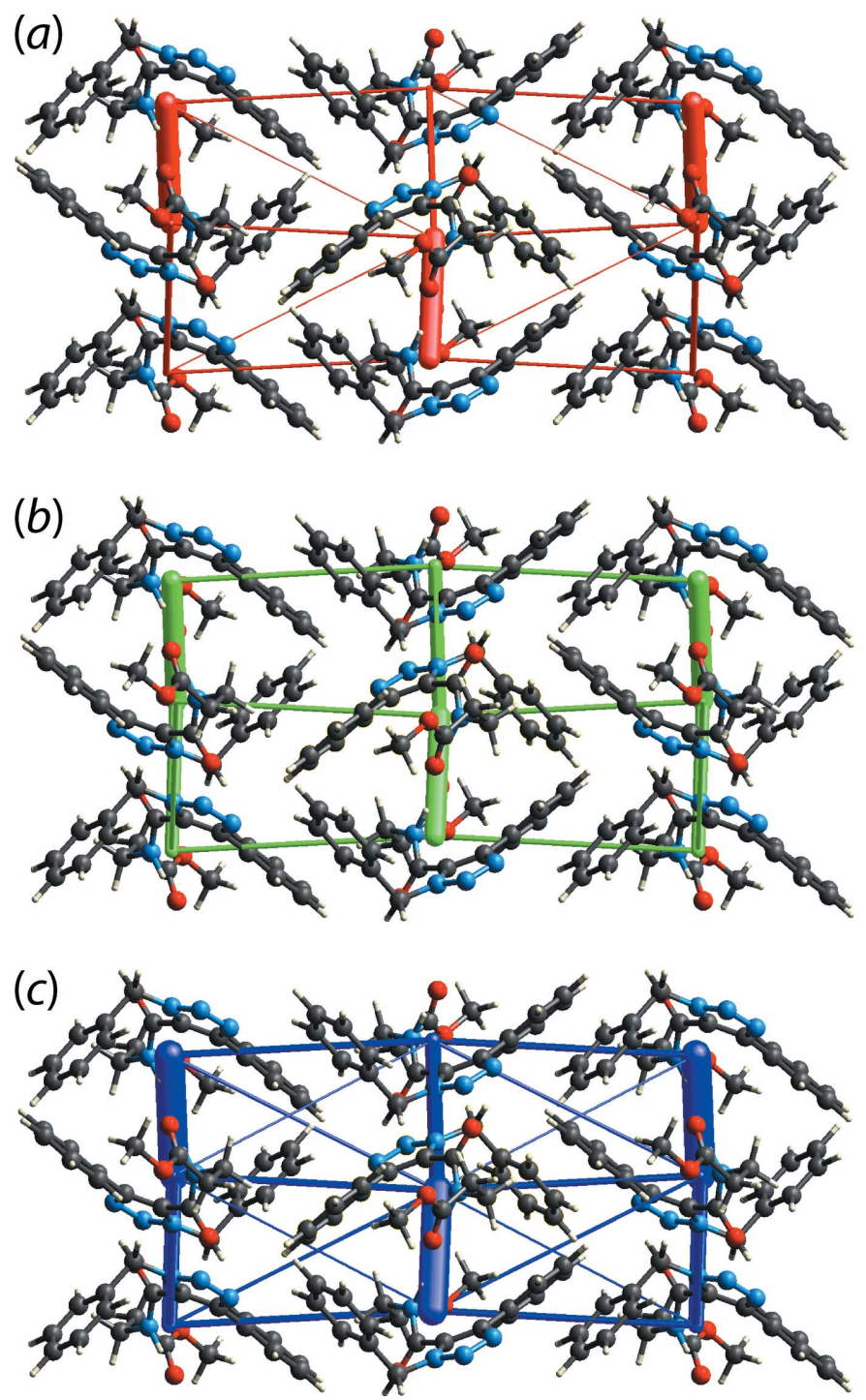

Figure 7

Perspective views of the energy frameworks calculated for (I) showing (a) electrostatic potential force, $(b)$ dispersion force and $(c)$ total energy, each plotted down the $a$ axis. The radii of the cylinders are proportional to the relative magnitudes of the corresponding energies and were adjusted to the same scale factor of 50 with a cut-off value of $5 \mathrm{~kJ} \mathrm{~mol}^{-1}$ within $1 \times 1 \times 1$ unit cells.

\section{Database survey}

There is a sole literature precedent for (I), namely the analogue with ethyl carboxylate and $N$-phenylamide substituents at the $\mathrm{C} 1$ - and $\mathrm{C} 2$-atoms, respectively (WAGROM; Katritzky et al., 2003), hereafter (II). An overlay diagram of (I) and (II) is given in Fig. 8. As anticipated, the five-membered rings and the $\alpha$-atoms of the three substituents exhibit close concordance but, beyond this, the molecular conformations of the terminal residues differ significantly.

\section{Synthesis and crystallization}

Compound (I) was prepared as described in the literature (de Albuquerque et al., 2019). The crystals were obtained by the slow evaporation from an ethanol solution of (I).

\section{Refinement details}

Crystal data, data collection and structure refinement details are summarized in Table 5. The carbon-bound $\mathrm{H}$ atoms were placed in calculated positions $(\mathrm{C}-\mathrm{H}=0.93-0.97 \AA)$ and were included in the refinement in the riding-model approximation, with $U_{\text {iso }}(\mathrm{H})$ set to $1.2-1.5 U_{\text {eq }}(\mathrm{C})$. The nitrogen-bound $\mathrm{H}$ atom was located in a difference Fourier map and refined with $\mathrm{N}-$ $\mathrm{H}=0.86 \pm 0.01 \AA$, and with $U_{\text {iso }}(\mathrm{H})$ set to $1.2 U_{\text {eq }}(\mathrm{N})$.

\section{Acknowledgements}

Regina H. A. Santos from IQSC-USP is thanked for the X-ray data collection. Ricardo S. Schwab from DQ-UFSCar is thanked for the generous gift of the sample.

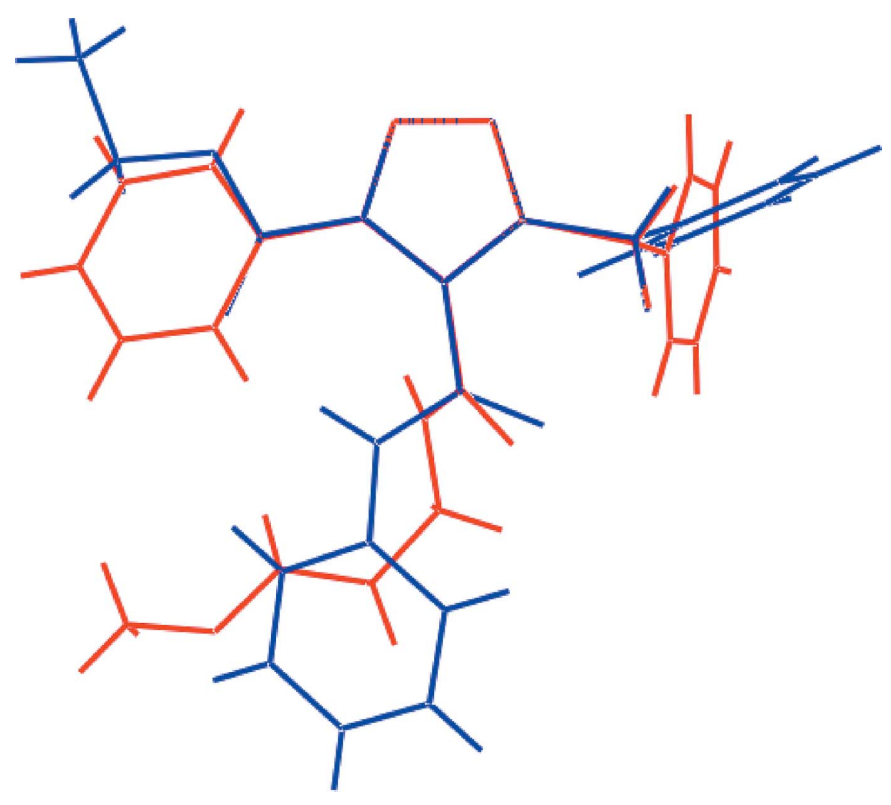

Figure 8

Overlay diagram for (I), red image, and (II), blue image. The molecules have been overlapped so the five-membered rings are superimposed. 


\section{Funding information}

The Brazilian agencies Coordination for the Improvement of Higher Education Personnel, CAPES, Finance Code 001 and the National Council for Scientific and Technological Development (CNPq) are acknowledged for grants 312210/2019-1, 433957/2018-2 and 406273/2015-4 to IC, for a fellowship $303207 / 2017-5$ to JZS. Sunway University Sdn Bhd is also thanked for funding (grant No. STR-RCTR-RCCM-0012019).

\section{References}

Albuquerque, D. Y. de, de Moraes, J. R. \& Schwab, R. S. (2019). Eur. J. Org. Chem. pp. 6673-6681.

Bonandi, E., Christodoulou, M. S., Fumagalli, G., Perdicchia, D., Rastelli, G. \& Passarella, D. (2017). Drug Discovery Today, 22, 1572-1581.

Brandenburg, K. (2006). DIAMOND. Crystal Impact GbR, Bonn, Germany.

Bruker (2009). APEX2, SAINT and SADABS. Bruker AXS Inc., Madison, Wisconsin, USA

Burla, M. C., Caliandro, R., Carrozzini, B., Cascarano, G. L., Cuocci, C., Giacovazzo, C., Mallamo, M., Mazzone, A. \& Polidori, G. (2015). J. Appl. Cryst. 48, 306-309.

ChemAxon (2010). Marvinsketch. http://www.chemaxon.com.

Edwards, A. J., Mackenzie, C. F., Spackman, P. R., Jayatilaka, D. \& Spackman, M. A. (2017). Faraday Discuss. 203, 93-112.

Farrugia, L. J. (2012). J. Appl. Cryst. 45, 849-854.

Katritzky, A. R., Zhang, Y., Singh, S. K. \& Steel, P. J. (2003). Arkivoc, pp. 47-64.

Mackenzie, C. F., Spackman, P. R., Jayatilaka, D. \& Spackman, M. A. (2017). IUCrJ, 4, 575-587.

McKinnon, J. J., Spackman, M. A. \& Mitchell, A. S. (2004). Acta Cryst. B60, 627-668.

Sheldrick, G. M. (2015). Acta Cryst. C71, 3-8.

Spackman, M. A., McKinnon, J. J. \& Jayatilaka, D. (2008). CrystEngComm, 10, 377-388.

Tan, S. L., Jotani, M. M. \& Tiekink, E. R. T. (2019). Acta Cryst. E75, 308-318.
Table 5

Experimental details.

\begin{tabular}{|c|c|}
\hline \multicolumn{2}{|l|}{ Crystal data } \\
\hline Chemical formula & $\mathrm{C}_{20} \mathrm{H}_{20} \mathrm{~N}_{4} \mathrm{O}_{3}$ \\
\hline$M_{\mathrm{r}}$ & 364.40 \\
\hline Crystal system, space group & Monoclinic, $P 2_{1} / c$ \\
\hline Temperature $(\mathrm{K})$ & 293 \\
\hline$a, b, c(\AA)$ & $\begin{array}{l}11.4312(14), 9.3013(10) \\
\quad 18.737(3)\end{array}$ \\
\hline$\beta\left(^{\circ}\right)$ & $104.695(4)$ \\
\hline$V\left(\AA^{3}\right)$ & $1927.1(4)$ \\
\hline$Z$ & 4 \\
\hline Radiation type & Mo $K \alpha$ \\
\hline$\mu\left(\mathrm{mm}^{-1}\right)$ & 0.09 \\
\hline Crystal size $(\mathrm{mm})$ & $0.46 \times 0.31 \times 0.24$ \\
\hline \multicolumn{2}{|l|}{ Data collection } \\
\hline Diffractometer & Bruker APEXII CCD \\
\hline Absorption correction & $\begin{array}{l}\text { Multi-scan (SADABS; Bruker } \\
\text { 2009) }\end{array}$ \\
\hline$T_{\min }, T_{\max }$ & $0.544,0.745$ \\
\hline $\begin{array}{l}\text { No. of measured, independent and } \\
\text { observed }[I>2 \sigma(I)] \text { reflections }\end{array}$ & $24191,3975,2965$ \\
\hline$R_{\text {int }}$ & 0.066 \\
\hline$(\sin \theta / \lambda)_{\max }\left(\AA^{-1}\right)$ & 0.628 \\
\hline \multicolumn{2}{|l|}{ Refinement } \\
\hline$R\left[F^{2}>2 \sigma\left(F^{2}\right)\right], w R\left(F^{2}\right), S$ & $0.077,0.204,1.08$ \\
\hline No. of reflections & 3975 \\
\hline No. of parameters & 249 \\
\hline No. of restraints & 1 \\
\hline $\mathrm{H}$-atom treatment & $\begin{array}{l}\mathrm{H} \text { atoms treated by a mixture of } \\
\text { independent and constrained } \\
\text { refinement }\end{array}$ \\
\hline$\Delta \rho_{\max }, \Delta \rho_{\min }\left(\mathrm{e} \AA^{-3}\right)$ & $0.23,-0.20$ \\
\hline
\end{tabular}

Computer programs: APEX2 and SAINT (Bruker, 2009), SIR2014 (Burla et al., 2015), SHELXL2018/3 (Sheldrick, 2015), ORTEP-3 for Windows (Farrugia, 2012), DIAMOND

(Brandenburg, 2006), MarvinSketch (ChemAxon, 2010) and publCIF (Westrip, 2010).

Turner, M. J., Mckinnon, J. J., Wolff, S. K., Grimwood, D. J., Spackman, P. R., Jayatilaka, D. \& Spackman, M. A. (2017). Crystal Explorer 17. The University of Western Australia.

Westrip, S. P. (2010). J. Appl. Cryst. 43, 920-925. 


\section{supporting information}

Acta Cryst. (2020). E76, 1051-1056 [https://doi.org/10.1107/S2056989020007380]

Methyl 3-[(1-benzyl-4-phenyl-1H-1,2,3-triazol-5-yl)formamido]propanoate: crystal structure, Hirshfeld surface analysis and computational chemistry

\section{Ignez Caracelli, Julio Zukerman-Schpector, Huey Chong Kwong and Edward R. T. Tiekink}

Computing details

Data collection: APEX2 (Bruker, 2009); cell refinement: SAINT (Bruker, 2009); data reduction: SAINT (Bruker, 2009); program(s) used to solve structure: SIR2014 (Burla et al., 2015); program(s) used to refine structure: SHELXL2018/3 (Sheldrick, 2015); molecular graphics: ORTEP-3 for Windows (Farrugia, 2012), DIAMOND (Brandenburg, 2006); software used to prepare material for publication: MarvinSketch (ChemAxon, 2010) and publCIF (Westrip, 2010).

Methyl 3-[(1-benzyl-4-phenyl-1H-1,2,3-triazol-5-yl)formamido]propanoate

Crystal data

$\mathrm{C}_{20} \mathrm{H}_{20} \mathrm{~N}_{4} \mathrm{O}_{3}$

$M_{r}=364.40$

Monoclinic, $P 2{ }_{1} / C$

$a=11.4312(14) \AA$

$b=9.3013(10) \AA$

$c=18.737(3) \AA$

$\beta=104.695(4)^{\circ}$

$V=1927.1(4) \AA^{3}$

$Z=4$

\section{Data collection}

Bruker APEXII CCD diffractometer

$\varphi$ and $\omega$ scans

Absorption correction: multi-scan

(SADABS; Bruker 2009)

$T_{\min }=0.544, T_{\max }=0.745$

24191 measured reflections

\section{Refinement}

Refinement on $F^{2}$

Least-squares matrix: full

$R\left[F^{2}>2 \sigma\left(F^{2}\right)\right]=0.077$

$w R\left(F^{2}\right)=0.204$

$S=1.08$

3975 reflections

249 parameters

1 restraint

Primary atom site location: structure-invariant direct methods
$F(000)=768$

$D_{\mathrm{x}}=1.256 \mathrm{Mg} \mathrm{m}^{-3}$

Mo $K \alpha$ radiation, $\lambda=0.71073 \AA$

Cell parameters from 6479 reflections

$\theta=2.5-23.9^{\circ}$

$\mu=0.09 \mathrm{~mm}^{-1}$

$T=293 \mathrm{~K}$

Irregular, colourless

$0.46 \times 0.31 \times 0.24 \mathrm{~mm}$

3975 independent reflections

2965 reflections with $I>2 \sigma(I)$

$R_{\text {int }}=0.066$

$\theta_{\max }=26.5^{\circ}, \theta_{\min }=1.8^{\circ}$

$h=-14 \rightarrow 14$

$k=-11 \rightarrow 11$

$l=-23 \rightarrow 23$

Secondary atom site location: difference Fourier map

Hydrogen site location: mixed

$\mathrm{H}$ atoms treated by a mixture of independent and constrained refinement

$w=1 /\left[\sigma^{2}\left(F_{\mathrm{o}}^{2}\right)+(0.0396 P)^{2}+3.4742 P\right]$

where $P=\left(F_{\mathrm{o}}{ }^{2}+2 F_{\mathrm{c}}{ }^{2}\right) / 3$

$(\Delta / \sigma)_{\max }<0.001$

$\Delta \rho_{\max }=0.23 \mathrm{e} \AA^{-3}$

$\Delta \rho_{\min }=-0.20$ e $\AA^{-3}$ 
Extinction correction: SHELXL-2018/3

(Sheldrick 2015),

$\mathrm{Fc}^{*}=\mathrm{kFc}\left[1+0.001 \mathrm{xFc}^{2} \lambda^{3} / \sin (2 \theta)\right]^{-1 / 4}$

Extinction coefficient: 0.0267 (19)

\section{Special details}

Geometry. All esds (except the esd in the dihedral angle between two 1.s. planes) are estimated using the full covariance matrix. The cell esds are taken into account individually in the estimation of esds in distances, angles and torsion angles; correlations between esds in cell parameters are only used when they are defined by crystal symmetry. An approximate (isotropic) treatment of cell esds is used for estimating esds involving l.s. planes.

Fractional atomic coordinates and isotropic or equivalent isotropic displacement parameters $\left(\AA^{2}\right)$

\begin{tabular}{|c|c|c|c|c|}
\hline & $x$ & $y$ & $z$ & $U_{\text {iso }} * / U_{\text {eq }}$ \\
\hline $\mathrm{O} 1$ & $0.3969(2)$ & $0.4513(3)$ & $0.43041(14)$ & $0.0558(7)$ \\
\hline $\mathrm{O} 2$ & $0.6787(3)$ & $0.0379(3)$ & $0.5049(2)$ & $0.0836(10)$ \\
\hline $\mathrm{O} 3$ & $0.8198(3)$ & $0.2035(3)$ & $0.5160(2)$ & $0.0829(10)$ \\
\hline N1 & $0.1976(2)$ & $0.4009(3)$ & $0.49963(14)$ & $0.0450(7)$ \\
\hline $\mathrm{N} 2$ & $0.1426(3)$ & $0.3888(4)$ & $0.55460(17)$ & $0.0635(9)$ \\
\hline N3 & $0.2173(3)$ & $0.3227(4)$ & $0.60901(16)$ & $0.0598(9)$ \\
\hline N4 & $0.4356(2)$ & $0.2164(3)$ & $0.45617(14)$ & $0.0409(6)$ \\
\hline $\mathrm{H} 4 \mathrm{~N}$ & $0.409(3)$ & $0.143(2)$ & $0.4749(18)$ & $0.049 *$ \\
\hline $\mathrm{C} 1$ & $0.3218(3)$ & $0.2907(3)$ & $0.58938(16)$ & $0.0399(7)$ \\
\hline $\mathrm{C} 2$ & $0.3086(3)$ & $0.3412(3)$ & $0.51805(16)$ & $0.0370(7)$ \\
\hline $\mathrm{C} 3$ & $0.1285(3)$ & $0.4596(4)$ & $0.42786(19)$ & $0.0527(9)$ \\
\hline $\mathrm{H} 3 \mathrm{~A}$ & 0.180906 & 0.520492 & 0.407502 & $0.063^{*}$ \\
\hline H3B & 0.062468 & 0.518335 & 0.435328 & $0.063 *$ \\
\hline $\mathrm{C} 4$ & 0.0785 & $0.3410(4)$ & $0.37406(18)$ & $0.0482(8)$ \\
\hline $\mathrm{C} 5$ & $0.1396(4)$ & $0.2962(5)$ & $0.3228(2)$ & $0.0691(12)$ \\
\hline H5 & 0.212880 & 0.338684 & 0.321872 & $0.083 *$ \\
\hline C6 & $0.0922(6)$ & $0.1895(7)$ & $0.2736(2)$ & $0.0986(19)$ \\
\hline H6 & 0.133334 & 0.158992 & 0.239445 & $0.118^{*}$ \\
\hline $\mathrm{C} 7$ & $-0.0168(7)$ & $0.1276(7)$ & $0.2749(3)$ & $0.111(2)$ \\
\hline $\mathrm{H} 7$ & -0.049067 & 0.054764 & 0.241663 & $0.133^{*}$ \\
\hline $\mathrm{C} 8$ & $-0.0772(6)$ & $0.1728(6)$ & $0.3245(3)$ & $0.1071(19)$ \\
\hline $\mathrm{H} 8$ & -0.151197 & 0.131428 & 0.324646 & $0.128^{*}$ \\
\hline C9 & $-0.0299(4)$ & $0.2792(5)$ & $0.3747(2)$ & $0.0707(12)$ \\
\hline H9 & -0.071464 & 0.308948 & 0.408779 & $0.085^{*}$ \\
\hline $\mathrm{C} 10$ & $0.4213(3)$ & $0.2167(3)$ & $0.64097(16)$ & $0.0410(7)$ \\
\hline C11 & $0.3958(4)$ & $0.1262(4)$ & $0.69416(19)$ & $0.0598(10)$ \\
\hline H11 & 0.316046 & 0.112350 & 0.695971 & $0.072 *$ \\
\hline $\mathrm{C} 12$ & $0.4876(6)$ & $0.0571(5)$ & $0.7442(2)$ & $0.0812(15)$ \\
\hline $\mathrm{H} 12$ & 0.469542 & -0.003111 & 0.779513 & $0.097^{*}$ \\
\hline $\mathrm{C} 13$ & $0.6056(5)$ & $0.0765(5)$ & $0.7421(2)$ & $0.0787(15)$ \\
\hline H13 & 0.667277 & 0.028938 & 0.775749 & $0.094 *$ \\
\hline $\mathrm{C} 14$ & $0.6325(4)$ & $0.1658(5)$ & $0.6906(2)$ & $0.0679(12)$ \\
\hline H14 & 0.712690 & 0.179290 & 0.689602 & $0.081^{*}$ \\
\hline $\mathrm{C} 15$ & $0.5411(3)$ & $0.2367(4)$ & $0.63968(18)$ & $0.0489(8)$ \\
\hline H15 & 0.560139 & 0.297321 & 0.604805 & $0.059 *$ \\
\hline
\end{tabular}




\begin{tabular}{lllll} 
C16 & $0.3854(3)$ & $0.3416(3)$ & $0.46468(16)$ & $0.0357(7)$ \\
C17 & $0.5073(3)$ & $0.1985(4)$ & $0.40222(19)$ & $0.0560(10)$ \\
H17A & 0.469697 & 0.251931 & 0.357879 & $0.067^{*}$ \\
H17B & 0.508059 & 0.097734 & 0.389017 & $0.067^{*}$ \\
C18 & $0.6360(3)$ & $0.2500(4)$ & $0.4315(2)$ & $0.0601(10)$ \\
H18A & 0.673282 & 0.260002 & 0.390743 & $0.072^{*}$ \\
H18B & 0.634970 & 0.344092 & 0.453692 & $0.072^{*}$ \\
C19 & $0.7104(3)$ & $0.1507(4)$ & $0.4873(2)$ & $0.0525(9)$ \\
C20 & $0.9011(5)$ & $0.1147(7)$ & $0.5700(4)$ & $0.116(2)$ \\
H20A & 0.864583 & 0.092823 & 0.609558 & $0.173^{*}$ \\
H20B & 0.975609 & 0.165410 & 0.589204 & $0.173^{*}$ \\
H20C & 0.917047 & 0.027061 & 0.547137 & $0.173^{*}$ \\
\hline
\end{tabular}

Atomic displacement parameters $\left(\AA^{2}\right)$

\begin{tabular}{lllllll}
\hline & $U^{11}$ & $U^{22}$ & $U^{33}$ & $U^{12}$ & $U^{13}$ & $U^{23}$ \\
\hline O1 & $0.0565(15)$ & $0.0461(14)$ & $0.0659(16)$ & $-0.0003(11)$ & $0.0177(12)$ & $0.0213(12)$ \\
O2 & $0.079(2)$ & $0.0530(17)$ & $0.114(3)$ & $-0.0147(15)$ & $0.0151(18)$ & $0.0224(17)$ \\
O3 & $0.0569(17)$ & $0.071(2)$ & $0.116(3)$ & $-0.0102(15)$ & $0.0128(17)$ & $0.0251(18)$ \\
N1 & $0.0430(15)$ & $0.0491(16)$ & $0.0420(14)$ & $0.0096(13)$ & $0.0092(12)$ & $-0.0051(12)$ \\
N2 & $0.0502(18)$ & $0.092(3)$ & $0.0525(18)$ & $0.0146(18)$ & $0.0204(15)$ & $-0.0114(18)$ \\
N3 & $0.0558(18)$ & $0.082(2)$ & $0.0465(17)$ & $0.0083(17)$ & $0.0218(14)$ & $-0.0051(16)$ \\
N4 & $0.0478(15)$ & $0.0374(14)$ & $0.0422(14)$ & $-0.0016(12)$ & $0.0203(12)$ & $0.0002(12)$ \\
C1 & $0.0442(17)$ & $0.0411(17)$ & $0.0365(15)$ & $0.0006(14)$ & $0.0140(13)$ & $-0.0057(13)$ \\
C2 & $0.0396(16)$ & $0.0311(15)$ & $0.0399(16)$ & $0.0042(13)$ & $0.0094(12)$ & $-0.0019(13)$ \\
C3 & $0.050(2)$ & $0.048(2)$ & $0.055(2)$ & $0.0155(16)$ & $0.0042(16)$ & $0.0014(16)$ \\
C4 & $0.0507(19)$ & $0.0495(19)$ & $0.0407(17)$ & $0.0144(16)$ & $0.0048(14)$ & $0.0016(15)$ \\
C5 & $0.076(3)$ & $0.084(3)$ & $0.049(2)$ & $0.021(2)$ & $0.018(2)$ & $0.001(2)$ \\
C6 & $0.128(5)$ & $0.113(5)$ & $0.048(2)$ & $0.037(4)$ & $0.009(3)$ & $-0.024(3)$ \\
C7 & $0.133(5)$ & $0.096(4)$ & $0.079(4)$ & $0.006(4)$ & $-0.019(4)$ & $-0.041(3)$ \\
C8 & $0.108(4)$ & $0.094(4)$ & $0.104(4)$ & $-0.032(3)$ & $-0.001(4)$ & $-0.024(4)$ \\
C9 & $0.062(3)$ & $0.082(3)$ & $0.064(2)$ & $-0.007(2)$ & $0.009(2)$ & $-0.014(2)$ \\
C10 & $0.059(2)$ & $0.0350(16)$ & $0.0297(14)$ & $0.0017(14)$ & $0.0129(13)$ & $-0.0044(12)$ \\
C11 & $0.093(3)$ & $0.052(2)$ & $0.0417(19)$ & $0.000(2)$ & $0.0307(19)$ & $0.0006(16)$ \\
C12 & $0.148(5)$ & $0.060(3)$ & $0.042(2)$ & $0.021(3)$ & $0.035(3)$ & $0.0155(19)$ \\
C13 & $0.119(4)$ & $0.070(3)$ & $0.038(2)$ & $0.037(3)$ & $0.002(2)$ & $0.0025(19)$ \\
C14 & $0.064(2)$ & $0.078(3)$ & $0.052(2)$ & $0.019(2)$ & $-0.0025(18)$ & $-0.005(2)$ \\
C15 & $0.057(2)$ & $0.048(2)$ & $0.0388(17)$ & $0.0015(16)$ & $0.0058(15)$ & $0.0003(15)$ \\
C16 & $0.0341(15)$ & $0.0349(16)$ & $0.0360(15)$ & $-0.0021(13)$ & $0.0053(12)$ & $0.0029(13)$ \\
C17 & $0.059(2)$ & $0.069(2)$ & $0.0475(19)$ & $0.0052(19)$ & $0.0267(17)$ & $-0.0019(17)$ \\
C18 & $0.058(2)$ & $0.059(2)$ & $0.072(2)$ & $0.0023(19)$ & $0.034(2)$ & $0.015(2)$ \\
C19 & $0.055(2)$ & $0.044(2)$ & $0.066(2)$ & $-0.0056(17)$ & $0.0293(18)$ & $0.0014(17)$ \\
C20 & $0.068(3)$ & $0.119(5)$ & $0.145(5)$ & $0.011(3)$ & $0.000(3)$ & $0.036(4)$ \\
& & & & &
\end{tabular}

Geometric parameters $\left(\AA,{ }^{o}\right)$

\begin{tabular}{llll}
\hline $\mathrm{O} 1-\mathrm{C} 16$ & $1.231(4)$ & $\mathrm{C} 7-\mathrm{H} 7$ & 0.9300 \\
$\mathrm{O} 2-\mathrm{C} 19$ & $1.184(4)$ & $\mathrm{C} 8-\mathrm{C} 9$ & $1.378(7)$
\end{tabular}




\begin{tabular}{|c|c|c|c|}
\hline $\mathrm{O} 3-\mathrm{C} 19$ & $1.324(5)$ & $\mathrm{C} 8-\mathrm{H} 8$ & 0.9300 \\
\hline $\mathrm{O} 3-\mathrm{C} 20$ & $1.446(6)$ & C9-H9 & 0.9300 \\
\hline $\mathrm{N} 1-\mathrm{N} 2$ & $1.341(4)$ & $\mathrm{C} 10-\mathrm{C} 15$ & $1.388(5)$ \\
\hline $\mathrm{N} 1-\mathrm{C} 2$ & $1.347(4)$ & $\mathrm{C} 10-\mathrm{C} 11$ & $1.391(5)$ \\
\hline $\mathrm{N} 1-\mathrm{C} 3$ & $1.480(4)$ & $\mathrm{C} 11-\mathrm{C} 12$ & $1.376(6)$ \\
\hline $\mathrm{N} 2-\mathrm{N} 3$ & $1.306(4)$ & C11-H11 & 0.9300 \\
\hline $\mathrm{N} 3-\mathrm{C} 1$ & $1.368(4)$ & $\mathrm{C} 12-\mathrm{C} 13$ & $1.371(7)$ \\
\hline $\mathrm{N} 4-\mathrm{C} 16$ & $1.326(4)$ & $\mathrm{C} 12-\mathrm{H} 12$ & 0.9300 \\
\hline $\mathrm{N} 4-\mathrm{C} 17$ & $1.464(4)$ & $\mathrm{C} 13-\mathrm{C} 14$ & $1.366(6)$ \\
\hline $\mathrm{N} 4-\mathrm{H} 4 \mathrm{~N}$ & $0.860(10)$ & $\mathrm{C} 13-\mathrm{H} 13$ & 0.9300 \\
\hline $\mathrm{C} 1-\mathrm{C} 2$ & $1.388(4)$ & $\mathrm{C} 14-\mathrm{C} 15$ & $1.389(5)$ \\
\hline $\mathrm{C} 1-\mathrm{C} 10$ & $1.464(4)$ & $\mathrm{C} 14-\mathrm{H} 14$ & 0.9300 \\
\hline $\mathrm{C} 2-\mathrm{C} 16$ & $1.489(4)$ & C15-H15 & 0.9300 \\
\hline $\mathrm{C} 3-\mathrm{C} 4$ & $1.506(5)$ & $\mathrm{C} 17-\mathrm{C} 18$ & $1.511(5)$ \\
\hline $\mathrm{C} 3-\mathrm{H} 3 \mathrm{~A}$ & 0.9700 & C17-H17A & 0.9700 \\
\hline $\mathrm{C} 3-\mathrm{H} 3 \mathrm{~B}$ & 0.9700 & C17-H17B & 0.9700 \\
\hline $\mathrm{C} 4-\mathrm{C} 9$ & $1.368(5)$ & $\mathrm{C} 18-\mathrm{C} 19$ & $1.489(5)$ \\
\hline $\mathrm{C} 4-\mathrm{C} 5$ & $1.387(5)$ & $\mathrm{C} 18-\mathrm{H} 18 \mathrm{~A}$ & 0.9700 \\
\hline $\mathrm{C} 5-\mathrm{C} 6$ & $1.370(7)$ & $\mathrm{C} 18-\mathrm{H} 18 \mathrm{~B}$ & 0.9700 \\
\hline $\mathrm{C} 5-\mathrm{H} 5$ & 0.9300 & $\mathrm{C} 20-\mathrm{H} 20 \mathrm{~A}$ & 0.9600 \\
\hline $\mathrm{C} 6-\mathrm{C} 7$ & $1.378(8)$ & $\mathrm{C} 20-\mathrm{H} 20 \mathrm{~B}$ & 0.9600 \\
\hline $\mathrm{C} 6-\mathrm{H} 6$ & 0.9300 & $\mathrm{C} 20-\mathrm{H} 20 \mathrm{C}$ & 0.9600 \\
\hline $\mathrm{C} 7-\mathrm{C} 8$ & $1.358(8)$ & & \\
\hline $\mathrm{C} 19-\mathrm{O} 3-\mathrm{C} 20$ & $116.5(4)$ & $\mathrm{C} 11-\mathrm{C} 10-\mathrm{C} 1$ & $119.2(3)$ \\
\hline $\mathrm{N} 2-\mathrm{N} 1-\mathrm{C} 2$ & $111.3(3)$ & $\mathrm{C} 12-\mathrm{C} 11-\mathrm{C} 10$ & $120.5(4)$ \\
\hline $\mathrm{N} 2-\mathrm{N} 1-\mathrm{C} 3$ & $118.9(3)$ & $\mathrm{C} 12-\mathrm{C} 11-\mathrm{H} 11$ & 119.7 \\
\hline $\mathrm{C} 2-\mathrm{N} 1-\mathrm{C} 3$ & $129.5(3)$ & $\mathrm{C} 10-\mathrm{C} 11-\mathrm{H} 11$ & 119.7 \\
\hline $\mathrm{N} 3-\mathrm{N} 2-\mathrm{N} 1$ & $107.3(3)$ & $\mathrm{C} 13-\mathrm{C} 12-\mathrm{C} 11$ & $120.3(4)$ \\
\hline $\mathrm{N} 2-\mathrm{N} 3-\mathrm{C} 1$ & $109.6(3)$ & $\mathrm{C} 13-\mathrm{C} 12-\mathrm{H} 12$ & 119.8 \\
\hline $\mathrm{C} 16-\mathrm{N} 4-\mathrm{C} 17$ & $121.3(3)$ & $\mathrm{C} 11-\mathrm{C} 12-\mathrm{H} 12$ & 119.8 \\
\hline $\mathrm{C} 16-\mathrm{N} 4-\mathrm{H} 4 \mathrm{~N}$ & $116(2)$ & $\mathrm{C} 14-\mathrm{C} 13-\mathrm{C} 12$ & $120.0(4)$ \\
\hline $\mathrm{C} 17-\mathrm{N} 4-\mathrm{H} 4 \mathrm{~N}$ & $121(2)$ & $\mathrm{C} 14-\mathrm{C} 13-\mathrm{H} 13$ & 120.0 \\
\hline $\mathrm{N} 3-\mathrm{C} 1-\mathrm{C} 2$ & $107.2(3)$ & $\mathrm{C} 12-\mathrm{C} 13-\mathrm{H} 13$ & 120.0 \\
\hline $\mathrm{N} 3-\mathrm{C} 1-\mathrm{C} 10$ & $120.6(3)$ & $\mathrm{C} 13-\mathrm{C} 14-\mathrm{C} 15$ & $120.6(4)$ \\
\hline $\mathrm{C} 2-\mathrm{C} 1-\mathrm{C} 10$ & $132.1(3)$ & $\mathrm{C} 13-\mathrm{C} 14-\mathrm{H} 14$ & 119.7 \\
\hline $\mathrm{N} 1-\mathrm{C} 2-\mathrm{C} 1$ & $104.6(3)$ & $\mathrm{C} 15-\mathrm{C} 14-\mathrm{H} 14$ & 119.7 \\
\hline $\mathrm{N} 1-\mathrm{C} 2-\mathrm{C} 16$ & $120.3(3)$ & $\mathrm{C} 10-\mathrm{C} 15-\mathrm{C} 14$ & $119.9(4)$ \\
\hline $\mathrm{C} 1-\mathrm{C} 2-\mathrm{C} 16$ & $135.2(3)$ & $\mathrm{C} 10-\mathrm{C} 15-\mathrm{H} 15$ & 120.1 \\
\hline $\mathrm{N} 1-\mathrm{C} 3-\mathrm{C} 4$ & $111.3(3)$ & $\mathrm{C} 14-\mathrm{C} 15-\mathrm{H} 15$ & 120.1 \\
\hline $\mathrm{N} 1-\mathrm{C} 3-\mathrm{H} 3 \mathrm{~A}$ & 109.4 & $\mathrm{O} 1-\mathrm{C} 16-\mathrm{N} 4$ & $123.9(3)$ \\
\hline $\mathrm{C} 4-\mathrm{C} 3-\mathrm{H} 3 \mathrm{~A}$ & 109.4 & $\mathrm{O} 1-\mathrm{C} 16-\mathrm{C} 2$ & $120.8(3)$ \\
\hline $\mathrm{N} 1-\mathrm{C} 3-\mathrm{H} 3 \mathrm{~B}$ & 109.4 & $\mathrm{~N} 4-\mathrm{C} 16-\mathrm{C} 2$ & $115.2(3)$ \\
\hline $\mathrm{C} 4-\mathrm{C} 3-\mathrm{H} 3 \mathrm{~B}$ & 109.4 & $\mathrm{~N} 4-\mathrm{C} 17-\mathrm{C} 18$ & $112.1(3)$ \\
\hline $\mathrm{H} 3 \mathrm{~A}-\mathrm{C} 3-\mathrm{H} 3 \mathrm{~B}$ & 108.0 & $\mathrm{~N} 4-\mathrm{C} 17-\mathrm{H} 17 \mathrm{~A}$ & 109.2 \\
\hline $\mathrm{C} 9-\mathrm{C} 4-\mathrm{C} 5$ & $119.7(4)$ & $\mathrm{C} 18-\mathrm{C} 17-\mathrm{H} 17 \mathrm{~A}$ & 109.2 \\
\hline $\mathrm{C} 9-\mathrm{C} 4-\mathrm{C} 3$ & $119.5(3)$ & $\mathrm{N} 4-\mathrm{C} 17-\mathrm{H} 17 \mathrm{~B}$ & 109.2 \\
\hline $\mathrm{C} 5-\mathrm{C} 4-\mathrm{C} 3$ & $120.7(4)$ & $\mathrm{C} 18-\mathrm{C} 17-\mathrm{H} 17 \mathrm{~B}$ & 109.2 \\
\hline
\end{tabular}




\begin{tabular}{|c|c|}
\hline $\mathrm{C} 6-\mathrm{C} 5-\mathrm{C} 4$ & $120.0(5)$ \\
\hline $\mathrm{C} 6-\mathrm{C} 5-\mathrm{H} 5$ & 120.0 \\
\hline $\mathrm{C} 4-\mathrm{C} 5-\mathrm{H} 5$ & 120.0 \\
\hline $\mathrm{C} 5-\mathrm{C} 6-\mathrm{C} 7$ & $119.8(5)$ \\
\hline $\mathrm{C} 5-\mathrm{C} 6-\mathrm{H} 6$ & 120.1 \\
\hline $\mathrm{C} 7-\mathrm{C} 6-\mathrm{H} 6$ & 120.1 \\
\hline $\mathrm{C} 8-\mathrm{C} 7-\mathrm{C} 6$ & $120.0(5)$ \\
\hline $\mathrm{C} 8-\mathrm{C} 7-\mathrm{H} 7$ & 120.0 \\
\hline $\mathrm{C} 6-\mathrm{C} 7-\mathrm{H} 7$ & 120.0 \\
\hline $\mathrm{C} 7-\mathrm{C} 8-\mathrm{C} 9$ & $120.7(6)$ \\
\hline $\mathrm{C} 7-\mathrm{C} 8-\mathrm{H} 8$ & 119.7 \\
\hline $\mathrm{C} 9-\mathrm{C} 8-\mathrm{H} 8$ & 119.7 \\
\hline $\mathrm{C} 4-\mathrm{C} 9-\mathrm{C} 8$ & $119.7(5)$ \\
\hline $\mathrm{C} 4-\mathrm{C} 9-\mathrm{H} 9$ & 120.1 \\
\hline $\mathrm{C} 8-\mathrm{C} 9-\mathrm{H} 9$ & 120.1 \\
\hline $\mathrm{C} 15-\mathrm{C} 10-\mathrm{C} 11$ & $118.7(3)$ \\
\hline $\mathrm{C} 15-\mathrm{C} 10-\mathrm{C} 1$ & $122.0(3)$ \\
\hline $\mathrm{C} 2-\mathrm{N} 1-\mathrm{N} 2-\mathrm{N} 3$ & $0.5(4)$ \\
\hline $\mathrm{C} 3-\mathrm{N} 1-\mathrm{N} 2-\mathrm{N} 3$ & $174.1(3)$ \\
\hline $\mathrm{N} 1-\mathrm{N} 2-\mathrm{N} 3-\mathrm{C} 1$ & $-0.3(4)$ \\
\hline $\mathrm{N} 2-\mathrm{N} 3-\mathrm{C} 1-\mathrm{C} 2$ & $-0.1(4)$ \\
\hline $\mathrm{N} 2-\mathrm{N} 3-\mathrm{C} 1-\mathrm{C} 10$ & $179.6(3)$ \\
\hline $\mathrm{N} 2-\mathrm{N} 1-\mathrm{C} 2-\mathrm{C} 1$ & $-0.6(4)$ \\
\hline $\mathrm{C} 3-\mathrm{N} 1-\mathrm{C} 2-\mathrm{C} 1$ & $-173.3(3)$ \\
\hline $\mathrm{N} 2-\mathrm{N} 1-\mathrm{C} 2-\mathrm{C} 16$ & $179.6(3)$ \\
\hline $\mathrm{C} 3-\mathrm{N} 1-\mathrm{C} 2-\mathrm{C} 16$ & $6.8(5)$ \\
\hline $\mathrm{N} 3-\mathrm{C} 1-\mathrm{C} 2-\mathrm{N} 1$ & $0.4(4)$ \\
\hline $\mathrm{C} 10-\mathrm{C} 1-\mathrm{C} 2-\mathrm{N} 1$ & $-179.3(3)$ \\
\hline $\mathrm{N} 3-\mathrm{C} 1-\mathrm{C} 2-\mathrm{C} 16$ & $-179.8(3)$ \\
\hline $\mathrm{C} 10-\mathrm{C} 1-\mathrm{C} 2-\mathrm{C} 16$ & $0.6(6)$ \\
\hline $\mathrm{N} 2-\mathrm{N} 1-\mathrm{C} 3-\mathrm{C} 4$ & $-97.4(4)$ \\
\hline $\mathrm{C} 2-\mathrm{N} 1-\mathrm{C} 3-\mathrm{C} 4$ & $74.8(5)$ \\
\hline $\mathrm{N} 1-\mathrm{C} 3-\mathrm{C} 4-\mathrm{C} 9$ & $85.4(4)$ \\
\hline $\mathrm{N} 1-\mathrm{C} 3-\mathrm{C} 4-\mathrm{C} 5$ & $-96.2(4)$ \\
\hline $\mathrm{C} 9-\mathrm{C} 4-\mathrm{C} 5-\mathrm{C} 6$ & $-0.7(6)$ \\
\hline $\mathrm{C} 3-\mathrm{C} 4-\mathrm{C} 5-\mathrm{C} 6$ & $-179.1(4)$ \\
\hline $\mathrm{C} 4-\mathrm{C} 5-\mathrm{C} 6-\mathrm{C} 7$ & $0.4(8)$ \\
\hline $\mathrm{C} 5-\mathrm{C} 6-\mathrm{C} 7-\mathrm{C} 8$ & $0.3(9)$ \\
\hline $\mathrm{C} 6-\mathrm{C} 7-\mathrm{C} 8-\mathrm{C} 9$ & $-0.8(10)$ \\
\hline $\mathrm{C} 5-\mathrm{C} 4-\mathrm{C} 9-\mathrm{C} 8$ & $0.2(7)$ \\
\hline $\mathrm{C} 3-\mathrm{C} 4-\mathrm{C} 9-\mathrm{C} 8$ & $178.6(4)$ \\
\hline $\mathrm{C} 7-\mathrm{C} 8-\mathrm{C} 9-\mathrm{C} 4$ & $0.6(9)$ \\
\hline
\end{tabular}

$\begin{array}{ll}\mathrm{H} 17 \mathrm{~A}-\mathrm{C} 17-\mathrm{H} 17 \mathrm{~B} & 107.9 \\ \mathrm{C} 19-\mathrm{C} 18-\mathrm{C} 17 & 112.9(3) \\ \mathrm{C} 19-\mathrm{C} 18-\mathrm{H} 18 \mathrm{~A} & 109.0 \\ \mathrm{C} 17-\mathrm{C} 18-\mathrm{H} 18 \mathrm{~A} & 109.0 \\ \mathrm{C} 19-\mathrm{C} 18-\mathrm{H} 18 \mathrm{~B} & 109.0 \\ \mathrm{C} 17-\mathrm{C} 18-\mathrm{H} 18 \mathrm{~B} & 109.0 \\ \mathrm{H} 18 \mathrm{~A}-\mathrm{C} 18-\mathrm{H} 18 \mathrm{~B} & 107.8 \\ \mathrm{O} 2-\mathrm{C} 19-\mathrm{O} 3 & 122.7(4) \\ \mathrm{O} 2-\mathrm{C} 19-\mathrm{C} 18 & 125.7(4) \\ \mathrm{O} 3-\mathrm{C} 19-\mathrm{C} 18 & 111.6(3) \\ \mathrm{O} 3-\mathrm{C} 20-\mathrm{H} 20 \mathrm{~A} & 109.5 \\ \mathrm{O} 3-\mathrm{C} 20-\mathrm{H} 20 \mathrm{~B} & 109.5 \\ \mathrm{H} 20 \mathrm{~A}-\mathrm{C} 20-\mathrm{H} 20 \mathrm{~B} & 109.5 \\ \mathrm{O} 3-\mathrm{C} 20-\mathrm{H} 20 \mathrm{C} & 109.5 \\ \mathrm{H} 20 \mathrm{~A}-\mathrm{C} 20-\mathrm{H} 20 \mathrm{C} & 109.5 \\ \text { H20B-C20-H20C } & 109.5 \\ & \end{array}$

$\mathrm{N} 3-\mathrm{C} 1-\mathrm{C} 10-\mathrm{C} 15 \quad-150.9$ (3)

$\mathrm{C} 2-\mathrm{C} 1-\mathrm{C} 10-\mathrm{C} 15 \quad 28.8(5)$

N3-C1-C10-C11 27.5 (5)

$\mathrm{C} 2-\mathrm{C} 1-\mathrm{C} 10-\mathrm{C} 11 \quad-152.8$ (4)

$\mathrm{C} 15-\mathrm{C} 10-\mathrm{C} 11-\mathrm{C} 12 \quad-0.5(5)$

$\mathrm{C} 1-\mathrm{C} 10-\mathrm{C} 11-\mathrm{C} 12 \quad-178.9$ (3)

$\mathrm{C} 10-\mathrm{C} 11-\mathrm{C} 12-\mathrm{C} 13 \quad 0.0(6)$

$\mathrm{C} 11-\mathrm{C} 12-\mathrm{C} 13-\mathrm{C} 14 \quad 0.5(7)$

$\mathrm{C} 12-\mathrm{C} 13-\mathrm{C} 14-\mathrm{C} 15 \quad-0.5(6)$

$\mathrm{C} 11-\mathrm{C} 10-\mathrm{C} 15-\mathrm{C} 14 \quad 0.5(5)$

$\mathrm{C} 1-\mathrm{C} 10-\mathrm{C} 15-\mathrm{C} 14 \quad 178.9$ (3)

$\mathrm{C} 13-\mathrm{C} 14-\mathrm{C} 15-\mathrm{C} 10 \quad 0.0(6)$

$\mathrm{C} 17-\mathrm{N} 4-\mathrm{C} 16-\mathrm{O} 1 \quad-2.0(5)$

$\mathrm{C} 17-\mathrm{N} 4-\mathrm{C} 16-\mathrm{C} 2 \quad 176.2(3)$

$\mathrm{N} 1-\mathrm{C} 2-\mathrm{C} 16-\mathrm{O} 1 \quad 46.0(4)$

$\mathrm{C} 1-\mathrm{C} 2-\mathrm{C} 16-\mathrm{O} 1 \quad-133.9$ (4)

$\mathrm{N} 1-\mathrm{C} 2-\mathrm{C} 16-\mathrm{N} 4 \quad-132.3$ (3)

$\mathrm{C} 1-\mathrm{C} 2-\mathrm{C} 16-\mathrm{N} 4 \quad 47.9(5)$

$\mathrm{C} 16-\mathrm{N} 4-\mathrm{C} 17-\mathrm{C} 18 \quad 82.3(4)$

$\mathrm{N} 4-\mathrm{C} 17-\mathrm{C} 18-\mathrm{C} 19 \quad 73.6(4)$

$\mathrm{C} 20-\mathrm{O} 3-\mathrm{C} 19-\mathrm{O} 2 \quad 0.8(7)$

$\mathrm{C} 20-\mathrm{O} 3-\mathrm{C} 19-\mathrm{C} 18 \quad-178.9(4)$

$\mathrm{C} 17-\mathrm{C} 18-\mathrm{C} 19-\mathrm{O} 2 \quad 5.0(6)$

$\mathrm{C} 17-\mathrm{C} 18-\mathrm{C} 19-\mathrm{O} 3 \quad-175.4(3)$ 
Hydrogen-bond geometry $\left(A,{ }^{\circ}\right)$

$C g 1$ is the centroid of the $(\mathrm{C} 10-\mathrm{C} 15)$ ring.

\begin{tabular}{lllll}
\hline$D-\mathrm{H} \cdots A$ & $D-\mathrm{H}$ & $\mathrm{H} \cdots A$ & $D \cdots A$ & $D-\mathrm{H} \cdots A$ \\
\hline $\mathrm{N} 4-\mathrm{H} 4 N \cdots \mathrm{O} 2^{\mathrm{i}}$ & $0.86(3)$ & $2.04(3)$ & $2.884(4)$ & $167(3)$ \\
$\mathrm{C} 3-\mathrm{H} 3 B \cdots \mathrm{N} 2^{\mathrm{ii}}$ & 0.97 & 2.55 & $3.495(5)$ & 165 \\
$\mathrm{C} 15-\mathrm{H} 15 \cdots \mathrm{O} 1^{\mathrm{iii}}$ & 0.93 & 2.51 & $3.335(5)$ & 148 \\
$\mathrm{C} 17-\mathrm{H} 17 B^{\cdots} \mathrm{Cg} 1^{\mathrm{i}}$ & 0.97 & 2.71 & $3.640(4)$ & 161
\end{tabular}

Symmetry codes: (i) $-x+1,-y,-z+1$; (ii) $-x,-y+1,-z+1$; (iii) $-x+1,-y+1,-z+1$. 